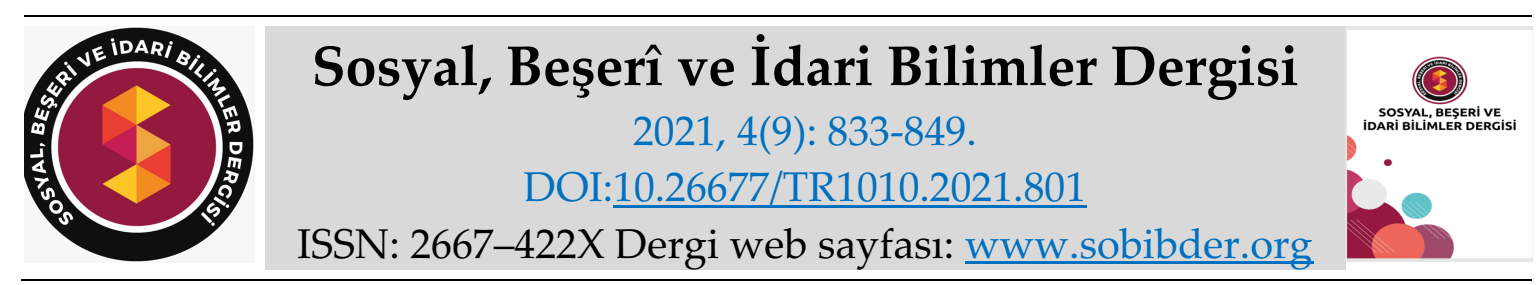

ARASTTIRMA MAKALESI

\title{
Uluslararası Pazarlarda Hedef Pazar Seçimi Üzerine Bir Araştırma
}

Ezgi DEMIRAĞ ÇAKICI, Yüksek Lisans Öğrencisi, Hacı Bayram Veli Üniversitesi, Lisansüstü Eğitim Enstitüsü, Ankara, e-posta: demiragezgi@gmail.com ORCID: https://orcid.org/0000-0001-6465-7632

Doç. Dr. Kadri Gökhan YILMAZ, Hacı Bayram Veli Üniversitesi, İşletme Fakültesi, Ankara, eposta: g.yilmaz@hbv.edu.tr

ORCID: https://orcid.org/0000-0002-3702-1070

Öz

Uluslararası pazarlara giriş için ilk adım olan hedef pazar seçiminin doğru ve etkin yapılması, firmaların ihracat hedeflerini yakalayabilmeleri ve arttırabilmeleri açısından kritik öneme sahiptir. Bu çalışmada kule vinç üreticisi olan bir firmayla uluslararası hedef pazar seçim çalışması hakkında görüşülmüştür. Hızlı sonuç alabilme, zaman ve maliyet avantajı nedeniyle ikincil verilerle uluslararası hedef pazar araştırmasını tercih eden firma pazarda ticari açık olması ve ithalat artışının olmasını hedef pazar seçim kriterleri olarak belirlemiştir. Analiz sonucunda firmanın İngiltere pazarını tek bir hedef pazarı olarak belirlediği görülmüştür. Çalışmada ayrıca kule vinç için ikincil veriler kullanılarak bir uluslararası hedef pazar seçim analizi yapılmıştır. Pazar büyüklügü, yıllara göre ithalat artışı, ülkede ticari açık olması temel kriterleri ile lojistik ve vergi avantajına göre yapılan analizde üç kriter içinde yer alan İngiltere, Arap Emirlikleri ve Belçika hedef pazarlar olarak belirlenmiştir. Ayrıca sadece iki kriter içinde yer alan ülkelerde hedef pazar olma potansiyeli açısından incelenmiştir. Pazar büyüklüğü ve ticari açık kriterlerine göre Suudi Arabistan ve İsviçre pazarları da hedef pazar olarak uygun bulunmuştur. Sonuç olarak bu çalışmada İngiltere, Arap Emirlikleri, Belçika, Suudi Arabistan ve İsviçre pazarları hedef pazarlar olarak karşımıza çıkmaktadır. Kule vinç sektörü üzerinden yapılan ikincil veri analizi, diğer sektör firmaları tarafından da uygulanarak, firmaların hem uluslararası pazarlara açılması hem de var olan ihracat hacimlerini büyütmeleri sayesinde ülkemiz ihracatına ve dolayısıyla ekonomik büyüme ve kalkınmaya destek sağlayacaktır.

Anahtar Kelimeler: Uluslararası Pazarlama, Uluslararası Pazarlarda Hedef Pazar Seçimi, Hedef Ülke, Uluslararası Pazarlama Araştırması.

Makale Gönderme Tarihi: 29.05.2021

Makale Kabul Tarihi: 02.09.2021

\section{Önerilen Atıf:}

Demirağ Çakıcı, E. ve Yılmaz, K. G. (2021). Uluslararası Pazarlarda Hedef Pazar Seçimi Üzerine Bir Araştırma, Sosyal, Beşeri ve İdari Bilimler Dergisi, 4(9): 833-849.

(C) 2021 Sosyal, Beşerî ve İdari Bilimler Dergisi. 


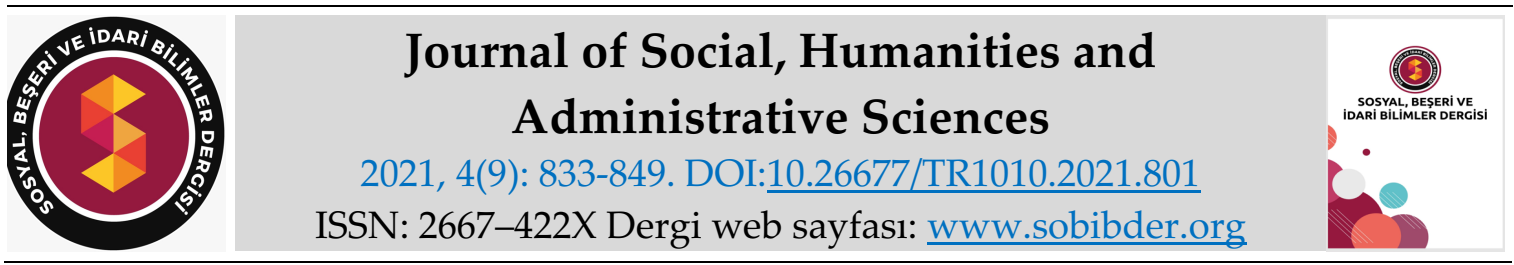

RESEARCH PAPER

\title{
A Research on Target Market Selection in International Markets
}

Ezgi DEMIRAĞ ÇAKICI, MSc. Student, Hacı Bayram Veli University, Graduate School of Education, Ankara, e-mail: demiragezgi@gmail.com ORCID: https://orcid.org/0000-0001-6465-7632

Associate Prof. Dr. Kadri Gökhan YILMAZ, Hacı Bayram Veli University, Faculty of Management, Ankara, e-mail: g.yilmaz@hbv.edu.tr ORCID: https://orcid.org/0000-0002-3702-1070

\begin{abstract}
Selecting a target market in a right and effective way, which is one of the very first steps of entering the international market, plays a significant role in achieving organization's export goals and enhancing them. In this study, using conducting interviews, one organization in tower crane sector was examined in terms of its goals and strategies in international target market selection. The company, which prefers international target market research with secondary data due to its fast results, time and cost advantage, has determined that the commercial deficit in the market and the increase in imports are the target market selection criteria. As a result of the analysis, it was seen that the company identified the UK market as a single target market. Besides in this study, using secondary data, international target market selection has been done for tower crane. The UK, Arab Emirates and Belgium, which are among the three criteria in the analysis based on market size, import growth by year, the basic criteria of having a trade deficit in the country and logistics and tax advantage, were identified as the target markets. In addition, it has been examined in terms of its potential to be a target market in countries within only two criteria. According to market size and trade deficit criteria, the Saudi Arabian and Swiss markets were also found to be suitable as target markets. As a result, the UK, Arab Emirates, Belgium, Saudi Arabia and Switzerland are the target markets in this study. Focusing on the sector of tower crane, secondary data analysis will make a significant contribution to other organizations in the same industry such that they can adapt the similar paths by entering the international market. Therefore, the study will contribute to those organizations to improve their export volumes and to achieve export-related goals as well as the growth and development of Turkey.
\end{abstract}

Keywords: International Marketing, Target Market Selection in International Markets, Target Country, International Marketing Research.

Received: 29.05.2021

Accepted: 02.09.2021

\footnotetext{
Suggested Citation:

Demirağ Çakıcı, E. and Yılmaz, K. G. (2021). A Research on Target Market Selection in International Markets, Journal of Social, Humanities and Administrative Sciences, 4(9): 833-849.

(C) 2021 Sosyal, Beşerî ve İdari Bilimler Dergisi.
} 


\section{Gíriş}

Günümüzde hızla artan rekabet sebebiyle işletmelerin uluslararası pazarlarda var olan pazar payını koruması ve yeni hedefler belirleyerek pazar payını arttırması zorunlu hale gelmiştir. Bu amaç doğrultusunda hedef pazar seçimi yaparken işletmelerin sahip olduğu kısıtlı kaynakları en doğru şekilde kullanarak, doğru stratejik kararlarla pazar seçim faaliyetlerini yönetmeleri gerekir.

Bu çalışmanın firmalar tarafından da uygulanmasıyla, firmaların uluslararası pazarlara açılması ya da var olan ihracatlarını arttırmaları sayesinde firmalara güçlü bir rekabet avantajı sağlayacak ve ülkemiz ihracatına ve dolayısıyla ekonomik büyüme ve kalkınmaya destek sağlayacaktır.

\section{KAVRAMSAL ÇERÇEVE}

\section{Hedef Ülke ve Pazarların Belirlenmesi}

Çağdaş pazarlama anlayışı ile hareket eden işletmelerde pazarlama faaliyetlerinin çıkış noktası, var olan ve potansiyel tüketicilerin oluşturduğu pazardır. İşletmelerin odak noktası tüketici davranışları, esas amaçları ise pazarlama karması unsurlarını etkin şekilde kullanarak müşteri tatmini ortaya çıkarmak, dolayısıyla da karlılığa ulaşmaktır (Kotler ve Keller, 2006: 3). Uluslararası pazarlama ise tüm bu çabaların uluslararası ortamda yürütülmesidir (Kozlu, 2011:9).

Uluslararası pazarlara girme kararı veren işletmeler için hangi pazara giriş, yapılacağı hayati önem taşımaktadır. Uluslararası pazarlara girişin ilk aşamalarında yanlış verilen hedef pazar seçim kararı işletmelerin uzun dönemli planları üzerinde olumsuz etkiler yaratmakta ve bu pazarlardaki büyüme faaliyetlerini olumsuz etkilemektedir (Hollensen, 2007: 320).

İşletmelerin uluslararası yöneliminin üretim, pazarlama, finansman, yönetim, muhasebe, insan kaynakları, halkla ilişkiler ve araştırma-geliştirme gibi temel işletme fonksiyonları üzerinde önemli etkisi olmaktadır (Mucuk, 2010).

$\mathrm{Bu}$ nedenle işletmelerin uluslararası pazarlara giriş stratejilerinde ilk olarak hedef ülke ve pazarları belirlemesi gereklidir. İşletmelerin hedef ülke ve pazarları belirlerken göz önünde bulundurmaları gereken faktörler aşağıdaki şekilde sıralanmıştır.

Pazar büyüklüğ̈̈ ve gelişme potansiyeli; dişsal faktörler içinde en önemli faktör pazarın büyüklügüdür. Bir ülkenin veya pazarın büyük olması ve pazarda büyüme oranının yüksek olması durumunda, işletmenin, pazarda büyümek için daha fazla kaynak ayırması ve kendine ait satış şubeleri kurması veya çoğunluğu kendine ait olan ortak girişimlere katılması gereklidir. Bu yöntemlerle işletmenin hedef pazarda kendini geliştirme imkânı ve pazar ile sürekli bağlantılı olma imkânı olur (Aksoy, 2013: 70). İşletmelerin dikkat etmesi gereken faktörlerden biri de pazarın ithalat ihtiyacı olması ve bu ihtiyacın sürekli bir artış gösteriyor olmasıdır. İthalat ihtiyacı olan ve bu ihtiyacı artan bir ülke cazip bir pazar olacağından işletmelerin bu faktörü göz önünde bulundurmaları gerekmektedir.

Risk, pazara giriş şeklini belirleyen diğer bir faktördür. Bir ülkedeki ekonomik veya politik konular işletmenin faaliyetlerini etkileyebilmektedir. Dolayısıyla bir ülkedeki risk faktörü ne kadar yüksekse işletmelerin o ülkede yapacakları yatırım düzeyi de buna bağlı olarak farklılık gösterecektir. Yani ortaklık yoluna gitmek yerine sadece ihracat yapmayı tercih edecektir. Burada bahsedilen risk ekonomik veya politik konularda olabileceği gibi işletmenin o pazardaki alacaklarını da etkileyecek bir unsurdur. Bu nedenle işletmeler yeni pazarlara girişte mutlaka risk analiz yaptırmalıdır (Terpstra ve Sarathy, 2000: 374). 
Kanun ve yönetmelikler; her ülkede işletmelerin uyacağı ticari konular, kanunlar ve yönetmelikler çerçevesinde belirlenmiştir. Fakat bazı ülkeler ticaretin önüne engeller koyabilmekte veya bazı standartlar getirebilmektedir. Bu durum bu ülkelerde yapılacak olan faaliyetlerin kısıtlanmasına sebep olabilir. Eğer bir ülkede yerli mal kullanıma yönelik bir eğilim varsa burada işletmelerin ortaklıklar kurma yoluyla pazar girişi avantaj sağlayacaktır veya işletmenin kendi ülkesinde olmayan yasalarla karşılaşması ve bu yasalara uyum sağlaması gerekecektir (Akyol, 2008: 328). Ayrıca işletmelerin ülkelerdeki gümrük vergisi, ithalat prosedürleri gibi konuları hedef pazar seçimi aşamasında araştırarak pazar seçimi yapmaları gerekmektedir.

Rekabetçi çeure; hedef ülke pazarında yoğun rekabet ortamının olması o pazarda elde edilecek kar potansiyelini ve pazar payını düşürecektir (Aksoy, 2013: 71). Bu nedenle hedef pazar seçimi yaparken pazardaki rakiplerin kimler olduğu, pazar payları, fiyat stratejileri göz önünde bulundurulmalıdır.

Yerel yapı; bir ülkedeki lojistik, dağıtım kanalı ve iletişim sistemlerini kapsamaktadır. Bir ülkede bu sistemlerin ne kadar ileri veya ne kadar zayıf olduğu pazara girişte işletmeleri etkileyecek bir diğer konudur. Eğer ülkede bu sistemler zayıfsa işletmenin bu ülke için kaynak ayırması zorlaşacaktır (Akyol vd., 2008: 328).

Ticari açı; ithalatı ihracatından fazla olan bir ülkenin ihracatı ile ithalatı arasındaki farkı göstermektedir. Ticari açık, ülkelerin bir ürün için ne kadar ithalat ihtiyacı olduğunu gösteren bir veridir. Ticari açık veren ülkeler hedef pazar seçiminde cazip ülkelerdir. Dolayısıyla hedef pazar seçimi yapılırken, hedef pazarda ihtiyaç durumu, ticari açık verisine göre incelenmelidir.

\section{Hedef Pazar Seçimi İçin Uluslararası Pazarlama Araştırması}

Uluslararası pazarlama en temel şekliyle, pazarlamanın temeli olan bilgi toplama, pazar bölümlendirme, hedef pazar seçimi, ürün geliştirme, fiyatlandırma, dağıtım ve tutundurma faaliyetlerinden bir veya birkaçının uluslararası alanda yapılmasıdır (Onkvisit ve Shaw, 1989:6).Uluslararası pazarlama ulusal sınırlar dışındaki tüketicilerin istek ve ihtiyaçlarını saptayarak daha sonra bunları ulusal ve uluslararası rakiplerden daha iyi karşılamak ve tatmin etmeyi içermektedir (Terpstra ve Sarathy, 2000: 173).

İşletmeleri uluslararası pazarlara yönlendiren iki önemli sebepten biri, işletmelerin yerel pazar payından daha fazlasını elde edebileceği yeni kaynaklara ihtiyacının olması diğer sebep ise ile ölçek ekonomisinden yararlanarak düşük maliyetle ürünlerini yeni pazara sunma isteğidir (Couturier ve Sola, 2010: 45-47).

İsletmelerin uluslararası pazarlara girmeyi düşünmesiyle başlayan süreçler bütünü uluslararasılaşma olarak tanımlanabilir. İşletmeler yürüttükleri faaliyetleri uluslararası alana taşırken strateji, yapı, kaynak vb. imkânlar ile uluslararası çevreye uyum sağlamaktadır (Çelik, Danacı ve Onay, 2015). İşletmelerin uluslararasılaşma yolunda belli aşamalardan geçtiği, geçilen her aşama sonrasında uluslararası pazarlama stratejilerini geliştirdiği kabul edilmektedir (Cateora ve Graham, 2005:17).

Uluslararası pazarlamada ana nokta hedef pazarın belirlenmesidir ve bu hedef pazara uygun bir pazarlama karmasının oluşturulması, bu karmanın da dış çevrenin hızlı değişimine uyum sağlayacak şekilde sürekli olarak gözden geçirilmesidir. Bu çalışma ve faaliyetler için gereken bilgiler pazarlama araştırması vasıtasıyla sağlanmaktadır (Akat, 2009: 33). Araştırma süreci aşağıdaki şekilde sıralanmıştır. 


\section{Bilgi Toplama}

Yöneticilerin uzun vadede sonuçlar doğuracak olan stratejik kararlar almadan önce, girecekleri ve faaliyet yapmak istedikleri uluslararası pazarların şu andaki ve gelecekteki durumunu, rekabet şartlarını, hedef tüketicilerin genel eğilim ve taleplerini, girmeyi planladıkları sektördeki strateji, hedef, durum ve şartlarını, o pazarların hareket tarzlarını sektörün gelişme koşullarını, pazar ve çevre şartlarını objektif, reel ve güvenilir bir şekilde görmeleri gerekmektedir. Bu nedenlerden dolayı pazarlama araştırmaları zaruri bir bilgi edinme süreci olmaktadır (Şekerkaya, 2008: 296).

\section{Problemin Belirlenmesi}

Bir işletmenin uluslararası pazarlarda karşılaştığı problemleri veya hareket tarzlarını veya önüne engel olarak gelen belirsizlikleri ortadan kaldırmak amacıyla, içinde olduğu durumu net bir şekilde çözmelidir. Bu netliği sıkı bir gözlem içerisine girerek ilk aşama olan bilgi ve veri toplama evresini ciddi bir denetim yaparak problemin ne olduğuna karar verebilir veya karşısına engel olarak çıkan herhangi bir sorunu ya da hareket tarzını elimine edebilmek için daha doğru sonuçlar ve kararlar elde edebilir (Akat, 2009:37).

\section{Araştırma Kapsamının Belirlenmesi}

Uluslararası pazarlama araştırmaları her ne kadar akademik yönüyle bilinse de aslında birçok durumda ticari önemde taşımaktadırlar. Ticari araştırmalara yönetimsel kararlar alınması sebebiyle ihtiyaç olduğu gibi, birçok durumda pazarlama faaliyetlerinin sürdürüldüğü coğrafi bölgeden dolayı ihtiyaç duyulmaktadır. Burada sözü edilen coğrafi bölge düzeyinde ihtiyaç duyulan veri ve bilgiler, küresel temelde olabildiği gibi, bir bölge veya ülke grubu düzeyinde ya da ülke ve şehir düzeyinde de olabilmektedir (Craig ve Douglas, 2005: 36).

\section{Veri Temin İmkanları}

Bilgi ve veri kaynakları temel olarak iki şekilde sınıflandırılmaktadır.

Birincil Veri Kaynakları: İkincil kaynaklarda istediği bilgilere ulaşamayan kişi veya kuruluşların, kendi çabalarıyla elde ettikleri, bilgilerin orijinal kaynaklarıdır. Birincil veriler başka bir yerde hazır olarak bulunmayan ve ilgili kaynağa soru sorularak ya da diğer araştırma yöntemleri kullanılarak, dolaysız yoldan toplanan bilgilerdir (Karafakığlu, 2012: 320). Bu tür araştırmalarda bilgi toplama süreci genellikle zaman, güç ve maliyet bakımından diğer veri toplama türlerine göre daha zahmetlidir. Birincil kaynaklara örnek olarak, orijinal belgeler, resmi kayıtlar, başta anket olmak üzere gözlem ve deney gibi yöntemler gösterilebilir (Akat, 2009: 45).

İkincil Veri Kaynakları: İkincil veri araştırmaları başka kişi ya da kurumlar tarafından yapılan ve genellikle yayınlanan verilerin bulunması ve incelenmesi ile gerçekleştirilir (Walsh, 1994: 57). Araştırma yapılan konu, uluslararası kuruluşlar, Ekonomi Bakanlığı, Ticaret Odası, ihracatçı birlikleri, bankalar ya da rakip işletmeler gibi kişiler ya da kurumlar tarafından daha önce araştırılmış olabilir. Bu nedenle pazar veya sektörle ilgili yapılan araştırmalar, bir masa başı araştırması yapılarak araştırılabilir, var olan kaynaklar ve referanslar incelenerek, telefon veya internet yoluyla bazı bilgiler elde edilerek durum analizi yapılabilir (Kozlu, 2011: 75). 
İkincil kaynak verilerin sağladığı en önemli faydalar maliyet ve zaman tasarrufudur. İkincil kaynak verilerin elde edilmesi birincil kaynak verilere göre daha kolaydır. Sadece araştırmacının verilerin yer aldığı kurumlara giderek, internet üzerinden ya da bir kütüphanede bir müddet zaman geçirmesi gerekmektedir. İkincil kaynak verilerin bir yerden satın alınması dahi birincil kaynak verileri uluslararası pazarlardan elde etmekten çok daha ucuza mal olmaktadır (Kumar, 2000: 89).

\section{Araştırma Tasarımı}

Bir problemin belirlenmesini sağlamak amacıyla, verilerin toplanması analiz edilmesi veya var olan bir problemin çözümüne yardımcı olacak, farklı seviyelerdeki doğruluğu elde etmenin maliyeti ile her seviyede doğruluğu elde etmeye destek olacak bilginin beklenen değeri arasındaki farkı maksimize etme yöntemidir (Tull ve Hawkins, 1984: 25).

\section{Verilerin Analizi ve Yorumlama}

Pazarlama araştırmasında veriler toplandıktan sonra bunların sınıflandırılması gerekmektedir. Sınıflandırma işleminin amacı toplanan ve hazır hale getirilmesi gereken bilgileri analiz işlemine tabi tutmaktır (Tokol, 2006: 60-64).

\section{YÖNTEM}

Bu çalışma ile kule vinç makinesi sektöründe faaliyet gösteren bir işletmenin uluslararası hedef pazar seçim süreci hakkında derinlemesine mülakat yapılmış ve kule vinç makinesi için veri tabanlarından elde edilen ikincil verilerle bir hedef pazar seçim analizi gerçekleştirilmiştir. Pazar seçimi ve uluslararasılaşma süreci her sektörün kendine özgü niteliklerden dolayı farklılaşabilir. Çalışma, farklı sektörlerde faaliyet gösteren işletmelerin doğru hedef pazar tercihi yaparak, uluslararası pazarlara açılması ya da hali hazırda devam eden ihracatlarını arttırmaları, artan ihracat sayesinde ise ülkemizin büyüme hedeflerinin gerçekleşmesine katkıda bulunulması açısından faydalı olabilecektir.

Bu çalışmada nitel araştırma yöntemi, kule vinç üreticisi firma yetkililerine, öncelikle kişiler özelinde olmak üzere, araştırmanın faydaları, firmaya katkıları, eksik ya da faydasız yönleri gibi verileri içeren soruların sorulması yoluyla uygulanmıştır. Çalışmada, araştırmaya katılan kişilerle yapılan görüşme sonrasında ayrıca ikincil verilerle yapılan uluslararası hedef pazar seçim analizi yer almaktadır.

Çalışma kapsamında incelenen işletme, 50 yıllık tecrübesiyle Ankara ilinde bulunmaktadır. Toplamda $1.000 .000 \mathrm{~m} 2$ üretim alanda 1000 personelin çalıştığ 1 firmada proje ve Ar-ge, kalite kontrol, CNC işleme, talaşlı imalat, ssıl işlem, boyama merkezleri ile geniş bir üretim kabiliyeti söz konusudur. Kule vinç üretimi ile birlikte geniş bir iş ve inşaat makineleri ürün gamı bulunan bir firmadır.

$\mathrm{Bu}$ araştırmada, kule vinç üreticisi bir firmayla uluslararası hedef pazar seçim hakkında görüşülmüş ve ikincil verilere dayalı analiz yapılmıştır. Araştırmada izlenen yol ve yöntemler vasıtasıyla, işletmelerin kaynaklarını en etkin şekilde kullanarak, en etkili olacağı uluslararası pazar veya pazarları seçmesine yardımcı olacak sonuçların ortaya çıkarılması amaçlanmıştır. 


\section{BULGULAR}

\section{Derinlemesine Mülakat Sonucu Elde Edilen Bulgular}

Çalışmada derinlemesine mülakat yöntemi kullanılmıştır. Derinlemesine mülakat yönteminde sorular araştırılan konunun bütün boyutlarını kapsar. Sorular açık uçludur ve detaylı cevap alınacak şekildedir. Derinlemesine görüşme yöntemi yüz yüze görüşülerek bilgi toplanmasını sağlayan bir veri toplama yöntemidir (Tekin ve Tekin, 2012). Derinlemesine mülakat tanımındaki derin kelimesi görüşülen kişinin gerçek hayatta yaşadığı günlük etkinlik, olay ve mekanların bütün yönleriyle anlaşılmasıdır (Johnson, 2002: 106).

$\mathrm{Bu}$ çalışmada yer alan soru formu sektör temsilcileri ile görüşmenin yanı sıra derinlemesine mülakat yöntemi kullanılan çalışmalar (Rahman, 2003; Moen, Gavlen ve Endresen, 2004; Andersen ve Strandskov, 2008; Okpara, 2009) incelenerek oluşturulmuştur.

Görüşme yapılan firma yetkililerinin, konuyla ilgili yeterli bilgi ve tecrübeye sahip oldukları, hedef pazar araştırmasıyla ilgili görüşlerinin gerçekçi olduğu ve soruları doğru ve samimi olarak cevapladıkları varsayılmıştır.

Katılımcların yaşları, eğitim durumları, işletmedeki görevleri, görev süreleri, daha önce çalıştıkları pozisyonlar ve toplam tecrübeleri hakkındaki sorular aşağıda bulunan Tablo 1'de yer almaktadır.

İşletmenizin ulusal pazarda tecrübesi bulunmakta mıdır?

Firmanın ulusal pazarda marka değerine sahip bir firma olduğu bilgisi aktarılmıştır. 1972 yılında kurulan firmanın 50 yıla yakın ulusal pazar tecrübesi olduğu görülmektedir. Çalışanların tamamının bu tecrübeyi dikkate alarak işletmeyi tercih etmesi dikkat çekmektedir. Aynı zamanda firmanın uluslararası faaliyetlerde bulunma kararında ulusal tecrübesinin cesaret verici olduğu konusuna çoğu katılımcı fikir birliğindedir.

İşletmenizin uluslararası pazarlarda tecrübesi bulunmakta mıdır?

Ulusal pazarlarda aktif olarak yer alan firmanın uluslararası pazarlarda da yer aldığı görülmektedir. Firmanın 2000 yılında iş ve inşaat makinalarıyla uluslararası pazarlarda faaliyet göstermeye başladığı, bugün ise uluslararası pazarlarda 50' ye yakın ülkeye ihracat yaptığı bilgisi aktarılmıştır.

İşletmeniz şu an faaliyet gösterdiğiniz pazarlar dışında farklı uluslararası pazarlara açılmak istiyor mu? İsteme veya istememe nedenleri nelerdir?

Firma hali hazırda uluslararası pazarlarda yer almaktadır. Katılımcılar firmanın hem marka değerini arttırmak hem de kar elde etmek temel amacıyla uluslararası pazarlara yönelik çalışmalarını arttırdığını aktarmışlardır. Firma bu amaç doğrultusunda hedef pazar seçim çalışmaları yapmaktadır.

İşletmenizde daha önce uluslararası pazarlara açılmak için hedef pazar araştırması yapıldı mı? Yapıldıysa hangi ürünler ve pazarlar için yapıldı?

Katılımcların çoğunun işletmenin geçmiş deneyim ve tecrübeleri ile ilgili bilgi sahibi oldukları görülmüştür. Özellikle yurt dişı sorumluluğu ile ithalat-ihracat birimlerinin konuya detaylı olarak hâkim oldukları anlaşılmıştır. Görüşmelerde hedef pazar araştırmasının daha önce yapıldığı ifade edilmiştir. Beton santralleri, beton pompaları ve kule vinçler öncelikli olmak üzere Rusya, Birleşik Krallık, Cezayir, Mısır ve Özbekistan pazarları için yapıldığı aktarılmıştır. 
Tablo 1. Katılımcı Bilgileri

\begin{tabular}{|c|c|c|c|c|c|c|}
\hline $\begin{array}{l}\text { Katılımcı } \\
\text { Bilgileri }\end{array}$ & Yaş & Eğitim & Görev & $\begin{array}{c}\text { Görev } \\
\text { Süresi } \\
\text { (y1) }\end{array}$ & Önceki Görevler & $\begin{array}{c}\text { Tecrübe } \\
\text { (yıl) }\end{array}$ \\
\hline Katılımcı & 37 & Lisans & $\begin{array}{c}\text { Genel } \\
\text { Müdür } \\
\text { Yardımcısı } \\
\end{array}$ & 15 & $\begin{array}{l}\text { Proje Mühendisi, } \\
\text { Arge Mühendisi, } \\
\text { Arge Grup Lideri }\end{array}$ & 18 \\
\hline Katılımcı & 35 & Lisans & $\begin{array}{c}\text { Marka } \\
\text { Pazarlama } \\
\text { Müdürü }\end{array}$ & 8 & $\begin{array}{c}\text { Grafik web } \\
\text { tasarımcı, Eğitmen, } \\
\text { Kurumsal İletişim } \\
\text { Sorumlusu, Reklam } \\
\text { Pazarlama Uzmanı }\end{array}$ & 12 \\
\hline Katılımcı & 35 & $\begin{array}{l}\text { Yüksek } \\
\text { Lisans } \\
\text { (MBA) }\end{array}$ & $\begin{array}{l}\text { İhracat } \\
\text { Müdürü }\end{array}$ & 4 & $\begin{array}{c}\text { İthalat Uzmanı, } \\
\text { İhracat Satış Bölge } \\
\text { Sorumlusu, İhracat } \\
\text { Operasyon Uzmanı, } \\
\text { İhracat Satış Bölge } \\
\text { Müdürü } \\
\end{array}$ & 13 \\
\hline Katılımcı & 37 & Lisans & $\begin{array}{l}\text { İthalat } \\
\text { Müdürü }\end{array}$ & 5 & $\begin{array}{c}\text { İhracat ve ithalat } \\
\text { uzmanı, İhracat } \\
\text { bölge sorumlusu, } \\
\text { İthalat bölge şefi }\end{array}$ & 16 \\
\hline Katılımcı & 34 & $\begin{array}{l}\text { Yüksek } \\
\text { Lisans }\end{array}$ & $\begin{array}{c}\text { Yurtdışı } \\
\text { Satış } \\
\text { Sorumlusu } \\
\end{array}$ & 2 & $\begin{array}{c}\text { Yurtdışı Satın alma } \\
\text { Uzmanı }\end{array}$ & 11 \\
\hline Katılımcı & 36 & Lisans & $\begin{array}{l}\text { Yurtdışı } \\
\text { Satış } \\
\text { Sorumlusu } \\
\end{array}$ & 3 & $\begin{array}{c}\text { Yurtdışı Satış } \\
\text { Uzmanı }\end{array}$ & 13 \\
\hline Katılımcı & 33 & Lisans & $\begin{array}{l}\text { Reklam } \\
\text { Pazarlama } \\
\text { Müdürü }\end{array}$ & 6 & $\begin{array}{c}\text { Grafik Tasarım } \\
\text { Uzmanı, Kurumsal } \\
\text { İletişim Sorumlusu, } \\
\text { Reklam Pazarlama } \\
\text { Uzmanı } \\
\end{array}$ & 8 \\
\hline Katılımcı & 40 & Lisans & $\begin{array}{l}\text { Tedarik ve } \\
\text { Lojistik } \\
\text { Müdürü }\end{array}$ & 15 & $\begin{array}{c}\text { Çelik Konstrüksiyon, } \\
\text { Talaşlı İmalat, Kalite } \\
\text { Kontrol } \\
\text { Departmanlarında } \\
\text { Takım Lideri }\end{array}$ & 15 \\
\hline
\end{tabular}

Pazar araştırmasını ihracat amaçlı mı yoksa ithalat amaçlı mı yapmak istiyorsunuz?

Firma hedef pazar araştırmasını, öncelikli olarak uluslararası pazarlara ihracat yapmak amacıyla gerçekleştirmektedir. Fakat çalışma ithalat amaçlı da kullanılabileceğinden katılımcılar firmanın çalışmayı ithalat amacıyla da kullanacağını aktarmışlardır.

Hedef pazar araştırmasını hangi ürün/ürünler için yapmak istiyorsunuz? Neden?

Katılımcılar, firmanın kule vinç ürününün hem kalite hem fiyat açısından ulusal ve uluslararası pazarlarda yer alan rakipler karşısında oldukça güçlü bir ürün olduğu için kule vinç başta olmak 
üzere, beton santrali, beton pompası, kırma eleme tesisi, iş makinaları için hedef pazar araştırması yapmak istediğini aktarmışlardır.

Hedef pazar araştırmasını birincil verilerle mi yoksa ikincil verilerle mi yaptınız? Seçiminizin nedenleri nelerdir?

Katılımcılar firmanın hem birincil hem de ikincil verileri kullanıldığı yönünde cevaplar vermişlerdir. Birincil verilerin fuarlar ve müşteri görüşmeleri esnasında toplandığı birkaç katılımcı tarafından belirtilmiştir. Katılımcılar ikincil verilerin hızlı elde edilmesi, zaman ve maliyet tasarrufu gibi faydaları nedeniyle tercih edildiği konusunda fikir birliğindedir.

Hedef pazar araştırmasını işletme bünyesinde mi yoksa dışarıdan hizmet alarak mı yaptınız?

Firmanın pazar araştırması konusunda dışarıdan hizmet aldığı ve bu çalışmayı firma bünyesinde oluşturulan bir ekiple gerçekleştirdiği aktarılmıştır.

Hedef pazar araştırmasında izlediğiniz yollar hakkında bilgi verir misiniz?

Katılımcılar hedef pazar araştırmasının aşamalarını sırasıyla aktarmışlardır. Öncelikle çalışma için gerekli olan Gtip ve SIC kodlarının tespit edilmesiyle Trade Map veri tabanından yıllara göre dünya ithalatı, yıllara göre dünya çeyrek dönemler ithalatı, dünya ithalatı ticaret göstergeleri, yıllara göre dünya ihracatı ve yıllara göre Türkiye ihracatı verileri elde edildiği, daha sonra ülkelerin kule vinç ürünü için uyguladığı vergi ve doküman şartlarını incelediği aktarılmıştır. Hedef pazarların elde edilen tüm bu veriler ve firma tercihleri doğrultusunda belirlendiği anlaşılmaktadır. Hedef ülkelerin belirlenmesiyle veri tabanlarını kullanarak firmaların finansal bilgilerine ve konşimento bilgilerine erişen firma, potansiyel tüm müşteri bilgilerini bir araya toplamıştır. Katılımcılar içerisinden oluşturulan bir çalışma grubuyla, tüm potansiyel müş̧terilere telefon veya e-posta yoluyla ulaşıldığı aktarılmıştır. Firmanın iletişim kurulan firmaları ziyaretlerle destekleyerek bayilik anlaşması aşamasına geldiği katılımcılar tarafından paylaşılmıştır.

Hedef pazar araştırması sonucu seçtiğiniz ihracat pazarlarını tercih etmenizin temel sebepleri nelerdir?

Katılımcılar hedef pazar seçimi için temel kriterlerin ülkelerin kule vinçürünü için ticari açığının olması ve ithalat verilerinin önceki yıllara göre göstermesi olduğu konusunda fikir birliğindedir.

Katılımcılar pazarda pazara giriş için herhangi bir engel olup olmaması (gümrük vergisi, tarife vs.), Türkiye'den ilgili ülkeye ihracatın olup olmaması, işletmenin ilgili ülkeye daha önce ihracatının olup olmaması, konum olarak Türkiye'ye yakın olup olmaması, ilgili ülkenin ithalat büyüklüğü, ortalama ithalat birim fiyatları ile ülkenin makroekonomik analizleri, siyasi gelişmeler, kültürel özellikler, vergi kanunları, güvenlik, bayi veya aracının da altyapısı, tecrübesi gibi kriterlere de dikkat edildiğini aktarmışlardır.

Katılımclar ayrıca düşük kalite ve düşük fiyat anlayışıla üretim yapan Çin'le düşük fiyat konusunda; yüksek kalite ve yüksek fiyat anlayışıyla üretim yapan $A B$ ülkeleriyle ise kalite konusunda rekabet edebileceği öngörüsüyle pazar tercihinde bulunduğunu aktarmışlardır.

İşletmenizin uluslararası pazarlara açlırken tercih ettiği pazarlama stratejileri nelerdir?

Katılımcıların cevaplarından firmanın doğrudan ihracata yönelik pazarlama stratejilerini kullanmakta olduğu bu doğrultuda acente/bayi ve distribütörlerle iş birliği yaparak pazarlama stratejilerini oluşturduğu anlaşılmaktadır. Katılımcılardan pazarlama bölümünde çalışanların aktardıklarına göre firma SMS ve e-posta gibi reklam tekniklerini içeren doğrudan posta, haber bültenleri, yurtiçi ve yurtdışı fuarlar ve internet reklamları kullanılmaktadır. 
Hedef pazar araştırmasının faydaları hakkındaki düşünceleriniz nelerdir? İşletmenize katkıları, kazandırdıkları neler olmuştur?

Katılımcılar, uluslararası pazarlama stratejilerinde kullanılacak verilerin saha araştırmasına kıyasla daha kısa sürede ve daha az maliyetle elde edilmesinin ve araştırmanın bilimsel temele dayanmasının bu çalışmanın en önemli faydaları olduğu konusunda fikir birliğindedir. Katılımcılar ayrıca uluslararası pazarlarda rekabet avantajı elde edilmesi, ihracat hedeflerine ulaşılması, doğru hedef pazar ve potansiyel müşterilere ulaşılması, marka bilinirliği ve farkındalığı gibi avantajlara da değinmiştir. Katılımcılar firmanın bu çalışmanın sonunda hedef pazar olarak İngiltere pazarını tercih ettiği ve vinç sektöründe potansiyel müşteri olabilecek 147 firma, yüksek bina inşaatı yapan potansiyel müşteri olabilecek 748 inşaat firması ve iş makinesi toptancısı olan potansiyel müşteri olabilecek 167 toptanc firmanın iletişim bilgilerine ulaştığı ve firmalarla iletişime geçilerek, bu pazarda bayilik çalışması yapıldığı bilgisini aktarmışlardır.

Yaptığınız pazar araştırmasının eksik, zayıf yönleri var mıdır? Varsa nelerdir?

Katılımcılar, çalışmanın en temel eksik yönleri olarak araştırmadaki tüm verilere eksiksiz ulaşmanın mümkün olmaması ve araştırma sonucunun firmaların tercihlerine göre değişken olması konularında fikir birliğindedir. Ayrıca hedef pazar seçimini etkileyebilecek nüfus artışı, kültürün pazarlamadaki etkileri, kalite, ürün standartları, pazardaki iç büyüme dinamikleri, yerli rakipler gibi faktörlerin analiz edilmemesi de araştırmanın eksik yönü olarak söylenmektedir.

Hedef pazar araştırmasının faydalarını ve eksik yönlerini göz önüne aldığınızda, araştırmayı bundan sonraki dönemler veya diğer ürünler için uygulamaya devam eder misiniz?

Katılımcılar, araştırmanın eksik ve faydalı tüm yönlerini göz önüne alarak faydalı yönlerinin ağırlıklı olması nedeniyle bundan sonraki süreçte hedef pazar analiz yöntemini uygulamaya devam edeceklerini açıkça ifade etmişlerdir.

\section{İkincil Veri Analizi Bulguları}

Literatürde ikincil verilerle Azerbaycan Cumhuriyeti devlet petrol şirketi (Mammadov, 2012), yüksek gerilim bağlantı elemanları (Küpcü, 2016), hasat ve harman makineleri sektörü (Altan, 2018), otomotiv yedek parça sektörü (Ödemiş, 2018), solar panel sektörü (Yüceer Yıldız, 2019) için uluslararası hedef pazar seçim çalışmaları yapılmıştır.

Bu çalışmada elde edilen ikincil veri analizlerine göre hedef pazar önerisi yapılmıştır. İkincil veri analizine göre hedef pazar tercihi yapabilmek için kriterler pazarın büyüklügüu, yıllara göre ithalat artışı ve ülkede ticari açığın olması, lojistik avantaj ve vergi avantajı olarak belirlenmiştir. Belirlenen kriterler içinden lojistik avantaj kriterinde bahsedilen avantaj bir maliyet avantajıdır. Fakat lojistik yakınlık km bazında ölçülebilir olmasına rağmen, lojistik maliyetlerinin km olarak yakınlığa göre hesaplanmaması nedeniyle ülke sıralaması yapmak mümkün olmamaktadır. Benzer şekilde vergi avantajı kriterinde bahsedilen bir maliyet avantajıdır. Türkiye ile aralarında gümrük anlaşması bulunan ülkelerde gümrük vergisi uygulanmamakta, Türkiye ile aralarında gümrük anlaşması bulunmayan ülkelerde ise her ülkeye göre gümrük vergi oranları değişmektedir. Gümrük vergisi uygulamayan çok sayıda ülke bulunması nedeniyle ülkeler içinde bir sıralama yapmak mümkün olmamaktadır. Bu nedenle hedef pazar seçerken öncelikle pazar büyüklüğü, ithalat artışı ve ticari açık kriterleri öncelikli kriterler olarak ele alınmış, daha sonra seçilen ülkeler lojistik ve vergi avantajına göre değerlendirilmiştir.

Trade Map veri tabanından elde edilen Dünya'da gerçekleşen kule vinç ithalat hacminin ülkelere göre dağılımını ve dünyadaki toplam ithalatı gösteren veriler aşağıda Tablo 2' de gösterilmiştir. 
Tablo 2. Gtip ‘842620’ için 2015- 2017 Yılları Arası Dünya İthalatı- 2017 Yılına Göre En Çok İthalat Yapan İlk 10 Ülke (.000 USD)

\begin{tabular}{|c|c|c|c|c|c|}
\hline İthalatçı & $\begin{array}{l}2015 \text { Itthalat } \\
\text { Verileri }\end{array}$ & $\begin{array}{l}2016 \text { İthalat } \\
\text { Verileri }\end{array}$ & $\begin{array}{l}2017 \text { İthalat } \\
\text { Verileri }\end{array}$ & $\begin{array}{c}\text { Artış } \\
\text { Miktarı }\end{array}$ & $\begin{array}{c}\text { Artış } \\
\text { Oranı } \\
(\%)\end{array}$ \\
\hline Dünya & 1.663 .934 & 1.512 .814 & 1.588 .174 & 75.360 & $\% 4,98$ \\
\hline Almanya & 86.778 & 109.365 & 134.667 & 25.302 & $\% 23,14$ \\
\hline Güney Kore & 106.143 & 175.445 & 109.243 & -66.202 & $\begin{array}{r}\%- \\
37,73 \\
\end{array}$ \\
\hline Amerika & 152.520 & 124.809 & 96.192 & -28.617 & $\begin{array}{r}\%- \\
22,93 \\
\end{array}$ \\
\hline İngiltere & 40.563 & 61.610 & 80.735 & 19.125 & $\% 31,04$ \\
\hline Fransa & 29.173 & 44.243 & 73.084 & 28.841 & $\% 65,19$ \\
\hline Arap Emirlikleri & 52.678 & 34.986 & 68.819 & 33.833 & $\% 96,70$ \\
\hline Belçika & 41.530 & 47.162 & 67.609 & 20.447 & $\% 43,35$ \\
\hline İsviçre & 40.966 & 55.593 & 66.502 & 10.909 & $\% 19,62$ \\
\hline Suudi Arabistan & 90.456 & 43.621 & 50.340 & 6.719 & $\% 15,40$ \\
\hline Avusturalya & 41.065 & 39.464 & 48.045 & 8.581 & $\% 21,74$ \\
\hline
\end{tabular}

Kaynak: www.trademap.org

Dünya'da kule vinç ithalatının en çok artış gösterdiği ülkeler aşağıdaki Tablo 3' te sıralanmıştır. 
Tablo 3. Gtip ‘842620’ için 2015- 2017 Yılları Arası Dünya İthalatı- 2017 Yılına Göre En Çok İthalat Artışı olan İlk 10 Ülke (.000 USD)

\begin{tabular}{|l|r|r|r|r|r|}
\hline \multicolumn{1}{|c|}{ İthalatçı } & $\begin{array}{c}\text { 2015 Ithalat } \\
\text { Verileri }\end{array}$ & $\begin{array}{c}\text { 2016 İthalat } \\
\text { Verileri }\end{array}$ & $\begin{array}{c}\text { 2017 Ithalat } \\
\text { Verileri }\end{array}$ & $\begin{array}{c}\text { Artış } \\
\text { Miktari }\end{array}$ & $\begin{array}{c}\text { Artış } \\
\text { Oranı } \\
\text { (\%) }\end{array}$ \\
\hline Meksika & 9.350 & 7.843 & 25.030 & 17.187 & $\% 219,14$ \\
\hline Endonezya & 27.750 & 11.764 & 24.493 & 12.729 & $\% 108,20$ \\
\hline Arap Emirlikleri & 52.678 & 34.986 & 68.819 & 33.833 & $\% 96,70$ \\
\hline İsveç & 5.143 & 12.666 & 24.540 & 11.874 & $\% 93,75$ \\
\hline İsrail & 26.060 & 20.152 & 34.566 & 14.414 & $\% 71,53$ \\
\hline Fransa & 29.173 & 44.243 & 73.084 & 28.841 & $\% 655,19$ \\
\hline Hollanda & 23.407 & 22.035 & 36.137 & 14.102 & $\% 64,00$ \\
\hline Belçika & 41.530 & 47.162 & 67.609 & 20.447 & $\% 43,35$ \\
\hline İngiltere & 40.563 & 61.610 & 80.735 & 19.125 & $\% 31,04$ \\
\hline Almanya & 86.778 & 109.365 & 134.667 & 25.302 & $\% 23,14$ \\
\hline
\end{tabular}

Kaynak: www.trademap.org

Kule vinç ürünü için en yüksek ticari açı̆̆ı bulunan ülkeler ise aşağıdaki Tablo 4 'te sıralanmıştır.

Tablo 4. Gtip: ‘842620’ için 2017 Yılı Dünya İthalatı Ticaret Göstergeleri (.000 USD)

\begin{tabular}{|l|c|c|}
\hline İthalatçı̈ Ülkeler & 2017 Y1lı İthalat Değeri (Bin USD) & $\begin{array}{c}\text { 2017 Yilı Ticari Açı (Bin } \\
\text { USD) }\end{array}$ \\
\hline Güney Kore & 109.243 & -99.566 \\
\hline İngiltere & 80.735 & -70.808 \\
\hline Amerika & 96.192 & -69.707 \\
\hline İsviçre & 66.502 & -61.191 \\
\hline Arap Emirlikleri & 68.819 & -50.875 \\
\hline Avusturalya & 48.045 & -43.222 \\
\hline Dünya & 1.588 .173 & -40.416 \\
\hline Suudi Arabistan & 50.340 & -40.215 \\
\hline Belçika & 67.609 & -39.859 \\
\hline Avusturya & 39.685 & -37.337 \\
\hline İsrail & 34.566 & -34.566 \\
\hline
\end{tabular}

Kaynak: www.trademap.org 
Pazar büyüklüğü, ithalat artışı ve ticari açık kriterleri için ülkeler aşağıdaki tablo 5'te sıralanmiştır.

Tablo 5: Pazar Büyüklüğü, İthalat Artışı, Ticari Açık Kriterlerine göre ilk 10 Ülke

\begin{tabular}{|l|l|r|r|}
\hline & \multicolumn{1}{|c|}{ Pazar Büyüklüğ̈̈ } & İthalat Artışı & \multicolumn{1}{c|}{ Ticari Açık } \\
\hline $\mathbf{1}$ & Almanya & Meksika & Güney Kore \\
\hline $\mathbf{2}$ & Güney Kore & Endonezya & İngiltere \\
\hline $\mathbf{3}$ & Amerika & Arap Emirlikleri & Amerika \\
\hline $\mathbf{4}$ & İngiltere & İsveç & İsviçre \\
\hline $\mathbf{5}$ & Fransa & İsrail & Arap Emirlikleri \\
\hline $\mathbf{6}$ & Arap Emirlikleri & Hollanda & Avusturalya \\
\hline $\mathbf{7}$ & Belçika & Belçika & Suudi Arabistan \\
\hline $\mathbf{8}$ & İsviçre & İngiltere & Belçika \\
\hline $\mathbf{9}$ & Suudi Arabistan & Almanya & Avusturya \\
\hline $\mathbf{1 0}$ & Avusturalya & İsrail \\
\hline
\end{tabular}

Üç kriter içinde yer alan ülkeler hedef pazarlar olarak belirlenmiştir. Buna göre hedef pazarlar İngiltere, Arap Emirlikleri ve Belçika olarak bulunmuştur. Pazar büyüklüğü, ithalat artışı ve ticari açık temel kriterlerinden sonra seçilen hedef pazarlar için vergi ve lojistik kriterleri de değerlendirilmiştir. Buna göre Arap Emirlikleri'nde gümrük vergisi oranı \%5'tir (http://madb.europa.eu/madb/indexPubli.htm). Birleşik Arap Emirlikleri'ndeki gümrük vergisi çok yüksek olmamasına rağmen bu ülkeye yapılacak ihracatlar da firmaların gümrük vergisini göz önüne almaları gerekmektedir. Avrupa ile Gümrük Birliği anlaşmasına ve İngiltere ile yapılan Serbest Ticaret Anlaşmasına göre Belçika ve İngiltere' de gümrük vergisi oranı \%0'dır.

Tablo 5'te bazı ülkelerin üç kriter yerine sadece iki kriter içinde yer aldığı görülmektedir. Bu durumda iki kriter içinde yer alan ülkelerin hedef pazar potansiyeli olup olmadığına dair bir değerlendirme yapılmıştır.

Suudi Arabistan, İsviçre ve Avusturalya pazarları hem pazar büyüklüğü hem de ticari açık kriterlerine göre cazip pazarlar olarak görülmektedir. Tablo 2'ye göre Suudi Arabistan'ın \%15,40, İsviçre'nin \%19,62, Avusturalya'nın ise \%21,74 büyüme artış oranı olduğu görülmektedir. Suudi Arabistan \%5 gümrük vergisi oranıla (www.customs.gov.sa) ve İsviçre (https://xtares.admin.ch) $\% 0$ gümrük vergisi avantajıyla hedef pazar olarak tercih edilebilir ülkeler olarak görülmektedir. Avusturalya ise lojistik dezavantajı nedeniyle hedef pazar olarak seçilmemiştir.

Güney Kore ve Amerika pazarları kule vinç sektöründe önemi büyük olan pazarladır. Dolayısıyla bu analizlerde de hem pazar büyüklüğü hem de ticari açık kriterlerinde yer alarak potansiyel hedef pazarlar olarak ortaya çıkmışlardır. Fakat tablo 2'ye göre ithalat artış oranlarına bakıldığında Güney Kore pazarının \%37, 73 Amerika pazarının ise \%22, 93 küçülmekte olduğu 
görülmektedir. Pazarların küçülmesi pazara yeni girecek olan işletmeler için olumsuz bir özellik olacağından bu pazarlar hedef pazar olarak tercih edilmemiştir.

Almanya ve Fransa pazarları ise sektörde Avrupa pazarının dikkat çeken pazarlarındandır. Analize göre hem pazar büyüklüğü hem de ithalat artışı kriterlerine göre cazip görünmesine rağmen Almanya'nın 134.667.000 USD Fransa'nın ise 73.829.000 USD ticari fazla verdikleri görülmektedir. Bu sonuca göre her iki pazarında doymuş pazarlar olduğu yani ithalat ihtiyaçlarının bulunmadığı görülmektedir. Bu nedenle Almanya ve Fransa pazarları da hedef pazar olarak tercih edilmemiştir.

\section{SONUÇ ve ÖNERILER}

Çalışmada kule vinç üreticisi olan bir firmanın ikincil verilerle uluslararası hedef pazar seçim çalışmasını gerçekleştiren 8 personeliyle görüşme yapılmıştır. Görüşmede öncelikle kişilerin yaş, eğitim, meslek ve deneyim gibi kişisel bilgileri elde edilmiştir. Görüşmede alınan cevaplara göre firma hedef pazar araştırmasını, uluslararası pazarlarda payını artırmak için gerçekleştirmiştir. Firmanın ikincil verilerle uluslararası hedef pazar araştırmasını, hızlı sonuç alabilme avantajı ile, zaman ve maliyet avantajı dolayısıyla tercih ettiği görülmektedir. Firma pazar seçim kriteri olarak pazarda ticari açık olması ve ithalat artışının olmasını temel kriterler olarak belirlemiştir. Analiz sonucunda firma İngiltere pazarını tek bir hedef pazarı olarak belirlemiştir. Firma hedef pazar seçiminde ikincil verilerin kullanılmasını çalışmanın bilimsel bir temele dayanması olarak görmektedir. Cevaplara göre ikincil veriler kullanarak hedef pazar seçiminin diğer avantajları ise pazarlarda rekabet avantajı elde edilmesi, ihracat hedeflerine ulaşılması, doğru hedef pazar ve potansiyel müşterilere ulaşılması, marka bilinirliğinin ve farkındalığının arttırılması olarak belirtilmiştir. Araştırmanın eksik yönleri ise verilerin tamamına ulaşmanın mümkün olmaması ve araştırmanın firma tercihlerine göre farklılık göstermesi olarak görülmektedir. Bunun dışında nüfus artışı, kültürün pazarlamadaki etkileri, kalite, ürün standartları, pazardaki iç büyüme dinamikleri, yerli rakipler gibi faktörlerin analiz sürecinde araştırılmaması da eksik yönler olarak belirtilmiştir.

İkincil veri analizine göre hedef pazar tercih kriterleri ise pazarın büyüklügü, yıllara göre ithalat artışı, ülkede ticari açığın olması, lojistik avantaj ve vergi avantajı olarak belirlenmiştir. Lojistik ve vergi avantajları için ülkeleri sıralamak mümkün olmadığından, ülkeler öncelikle pazar büyüklüğü, ithalat artışı ve ticari açık kriterlerine göre sıralanmıştır. Bu kriterlerde yer alan ülkeler daha sonra lojistik ve vergi avantajı kriterlerine göre incelenmiştir. Üç kriter içinde yer alan İngiltere, Arap Emirlikleri ve Belçika lojistik ve vergi avantajı da olması nedeniyle hedef pazarlar olarak belirlenmiştir. Daha sonra üç kriter dışında sadece iki kriter içinde yer alan ülkeler de hedef pazar olma açısından incelenmiştir. Pazar büyüklüğü ve ticari açık kriterlerine göre Suudi Arabistan ve İsviçre pazarları, lojistik ve vergi avantajı da olması nedeniyle hedef pazarlar olarak belirlenmiştir. Dolayısıyla ikincil verilerle yapılan bu çalışmada İngiltere, Arap Emirlikleri, Belçika, Suudi Arabistan ve İsviçre pazarları hedef pazarlar olarak karşımıza çıkmaktadır.

Hedef pazar seçimi yapısı gereği güncel, dinamik ve değişkendir. Görüldüğü üzere çalışmayı gerçekleştiren firma hedef pazar olarak İngiltere pazarını tek bir pazarı hedef olarak belirlemiştir. Fakat ikincil verilerle yapılan analize göre, İngiltere dışında Arap Emirlikleri, Belçika, Suudi Arabistan ve İsviçre pazarları da hedef pazarlar belirlenmiştir. Dolayısıyla firmanın İngiltere pazarı dışındaki diğer potansiyel pazarları değerlendiremediği görülmektedir.

Genel çerçeveden bakıldığında diğer sektör firmaları tarafından uygulanabilir bir analiz olması, firmaların hem uluslararası pazarlara açılması hem de var olan ihracat hacimlerini büyütmeleri 
sayesinde ülkemiz ihracatına ve dolayısıyla ekonomik büyüme ve kalkınmaya destek sağlayacak olması bu çalışmanın en büyük katkılarından biridir.

İkincil veri analiziyle elde edilen bilgileri, bir firmanın ancak yapacağı araştırmalar, seyahatler, firma görüşmeleri, fuarlar vb. yöntemler sayesinde elde edebileceği düşünüldüğünde, hedef pazar seçiminde ikincil verilerin kullanılması, firmalara hem zaman hem maliyet avantajı sağlayacaktır. Ayrıca firmaların ellerindeki iş gücü kaynağını daha etkili kullanmasını sağlayacağı da görülmektedir. Günümüz rekabet koşulları göz önüne alındığında çalışmanın uluslararası pazarlara açılan firmalara rekabet avantajı sağlaması ve ihracat artışı sağlaması çalışmanın en önemli katkılarından biridir.

İkincil veri analizlerinin işletmelere uluslararası pazarlara açılırken genel anlamda bir çıkış noktası ve yol gösterici olacağı söylenebilir. Çalışma sadece uluslararası pazarlara açılmak isteyen ya da hedef pazar seçimi yapacak işletmelere değil aynı zamanda hali hazırda uluslararası pazarlarda faaliyet gösteren işletmelerinde ellerindeki bilgilerini kıyaslayabilecekleri, güncelleyebilecekleri ve gözden kaçırılan konuların ortaya çıkarılması için bilimsel bir kaynak niteliği taşımaktadır. Tüm faydaları göz önüne alındığında firmalar uluslararası hedef pazar seçimi yaparken ikincil verileri dikkate alabilirler.

Firmaların uluslararası pazarlardaki hedeflerini yakalayabilmeleri açısından hedef pazar seçimi kritik bir öneme sahiptir. Bu nedenle firmalar uluslararası hedef pazar seçimi yaparken ikincil verileri temel bir kaynak olarak kullanabilirler.

Bu çalışmada uluslararası hedef pazar seçimi kule vinç sektörü üzerinden yapılmış olmasına rağmen araştırmada yer alan yol ve araştırma yöntemleri diğer sektörler içinde uygulanabilir. Bu nedenle farklı sektörlerde faaliyet gösteren işletmeler de benzer bir çalışmayı kolaylıkla kendi alanlarında yürütebilirler.

Uluslararası pazarlara ilk kez açılacak olan, ihracata yeni başlayan, zaman, maliyet, işgücü kaynakları kısıtlı olan firmalar başta olmak üzere uluslararası hedef pazar seçimi yapacak olan tüm firmaların ikincil verileri kullanarak hedef pazar seçimi yapmaları tavsiye edilir.

Çalışmanın tüm bu faydalarının yanı sıra eksik yönlerinin de bulunduğundan da bahsetmek gerekir. Öncelikle hedef pazar seçim kriterlerinin firma bazında değişiklik göstermesi araştırmanın sonucunu etkileyen en önemli faktörlerden birisi olmaktadır. Hedef pazar seçiminin için tek bir doğrudan veya geçerli tek bir seçimden söz etmek pek mümkün değildir. Hedef pazarlar firmaların belirlediği pazar seçim kriterlerine göre farklılık gösterecektir. Bundan sonraki çalışmalarda hedef pazar seçimi yapılırken bu çalışmada belirlenen hedef pazar seçim kriterleri dışında, pazardaki riskler, kanunlar, rakip çevre, yerel yapı gibi dışsal faktörlerle işletme ve ürünle ilgili içsel faktörlerin de araştırılması uygun olacaktır. Ayrıca, veri tabanlarından elde edilen bilgilerin dönemsel olarak güncellenmesi nedeniyle, analizin de dönemsel olarak tekrarlanması ve seçimlerin tekrar gözden geçirilmesi, büyüme görülen pazarlara göre yeni pazarlar eklenmesi ya da düşüş görülen pazarların seçimlerden çıarılması gereklidir.

\section{KAYNAKÇA}

Akat, Ö. (2009). Uluslararası Pazarlama: Karması ve Yönetimi. (7. Baskl), Bursa: Ekin Kitapevi.

Aksoy, Ş. (2013). Uluslararası Pazarlama, (Editör) Aksoy Ş. ve Barış G.: Uluslararası Pazarlama: Kavramlar ve Kapsam içinde (ss: 3-24) Eskişehir: Anadolu Üniversitesi.

Akyol, A. (2008). Küresel Pazarlama Yönetimi. (1. Baskl), İstanbul: Beta Yayınları. 
Altan, M. (2018). Uluslararası Pazarlamada İkincil Veriler Kullanılarak Hedef Pazar Seçimi ve Bir Model Önerisi, Yüksek Lisans Tezi, KTO Karatay Üniversitesi, Konya.

Andersen, P. H. and Strandskov, J. (2008). International Market Selection: A Cognitive Mapping Perspective, Journal of Global Marketing, 11 (3): 65-84.

Cateora, P. and Graham, J. (2005). International Marketing. (13. Edition), Boston: McGrew-Hill.

Couturier, J. and Sola D. (2010). International Market Entry Decisions: The Role of Local Market Factors, Journal of General Management, 35 (4): 45-63.

Craig, C. S. and Douglas, S.P. (2005). International Marketing Research. (3. Edition), New York: John Wiley \& Sons Ltd.

Çelik, A., Danacı, T., ve Onay, M. (2015). Uluslararasılaşmanın Markalaşmadaki İtici Gücü: İnci Akü Üzerine Bir Çalışma, Marmara Üniversitesi Öneri Dergisi, 11 (43): 47-69.

Hollensen, S. (2007). Global Marketing: A Decision- Oriented Approach, Harlow: Prentice Hall.

Johnson, J. M. (2002). In-Depth Interviewing, Handbook of Interview Research Context \& Method, London: Sage Publications.

http://www.customs.gov.sa [Erişim Tarihi: 01.03.2021].

http://madb.europa.eu/madb/indexPubli.htm [Erişim Tarihi: 01.03.2021].

http://www.gumruktarife.com [Erişim Tarihi: 01.03.2021].

https://www.trademap.org [Erişim Tarihi: 01.03.2021].

https://xtares.admin.ch [Erişim Tarihi: 01.03.2021].

Karafakığlu, M. (2012). Uluslararası Pazarlama Yönetimi: Teori, Uygulama ve Örnek Olaylar, İstanbul: Beta Yayınları.

Kotler, P. and Keller, K. (2006). Marketing Management (12. Baskı). Newjersey: Prentice Hall.

Kozlu, C. (2011). Uluslararası Pazarlama İlkeler ve Uygulamalar (12. Baskı), İstanbul: Türkiye İş Bankası Yayınları.

Kumar, V. (2000). International Marketing Research. New Jersey: Prentice Hall.

Küpcü, A. (2016) İkincil Verilerin İhracat Pazar Araştırmalarında Kullanımına Yönelik Etkinliği ve Bir Model Önerisi, Yüksek Lisans Tezi, KTO Karatay Üniversitesi, Konya.

Moen, Ø., Gavlen, M. and Endresen, I. (2004). Internationalization of small, computer software firms: Entry forms and market selection, European Journal of Marketing, 38 (9/10): 1236-1251.

Onkvisit, S. and Shaw, J. (1989). International Marketing. Ohio: Merrill Publishing Company.

Rahman, S.H. (2003). Modelling of international market selection process: a qualitative study of successful Australian international business, Qualitative Market Research, 6 (2): 119-132.

Şekerkaya, A. (2008). Küresel Pazarlama Yönetimi. İstanbul: Yazın Yayın ve Matbaacılık.

Tekin, H. ve Tekin, H. (2012). Nitel Araştırma Yönteminin Bir Veri Toplama Tekniği Olarak Derinlemesine Görüşme, İstanbul University Journal of Sociology, 3 (13): 101-116.

Terpstra, V. and Sarathy, R. (2000). International Marketing. (8. Edition), USA: The Dreyden Press.

Tokol, T. (2006). Pazarlama Araştırması. (12. Baskı), Ankara: Nobel Yayıncllık. 
Tull, D.S. and Hawkins, D.I. (1984). Marketing Research, Management and Method, a Text with Cases. (3. Edition), USA: Macmillan Publishing Company.

Mammadov, E. (2012). Uluslararası Hedef Pazar Seçimi ve Uluslararası Pazarlara Giriş Stratejileri: Azerbaycan Cumhuriyeti Devlet Petrol Şirketi Örneği, Yüksek Lisans Tezi, Ankara Üniversitesi, Ankara.

Mucuk, İ. (2010). Modern İşletmecilik. (18. Baskı), İstanbul: Türkmen Kitapevi.

Okpara, J.O. (2009). Strategic choices, export orientation and export performance of SMEs in Nigeria, Management Decision, 47 (8): 1281-1299.

Ödemiş, A. (2018). Rekabet İstihbaratı Temelli Yaklaşım ile İhracat Pazarlamasında Hedef Pazar Tespiti ve Otomotiv Yedek Parça Sektörü Uygulama Örneği, Yüksek Lisans Tezi, Necmettin Erbakan Üniversitesi, Konya.

Walsh, L. S. (1994). International Marketing. (3. Edition), Glasgow: Pitman Publishing.

Yüceer Yıldız, M. (2019). Uluslararası Hedef Pazar Seçiminde Rekabet İstihbaratının Rolü ve Önemi, Solar Panel Sektörü Özelinde Bir Değerlendirme, Yüksek Lisans Tezi, Başkent Üniversitesi, Ankara. 